\title{
The Case of the Kaliña and Lokono Peoples v. Suriname and the UN Declaration on the Rights of Indigenous Peoples: Convergence, Divergence and Mutual Reinforcement
}

\author{
Fergus MacKay
}

\begin{abstract}
The judgment of the Inter-American Court of Human Rights in the case of Kaliña and Lokono Peoples v. Suriname is noteworthy for a number of reasons. Particularly important is the Court's repeated citation and incorporation of various provisions of the 2007 United Nations Declaration on the Rights of Indigenous Peoples into its interpretation of the American Convention on Human Rights. This aids in greater understanding of the normative value of the Declaration's provisions, particularly when coupled with the dramatic increase in affirmations of that instrument by UN treaty bodies, Special Procedures and others. The Court's analysis also adds detail and further content to the bare architecture of the Declaration's general principles and further contributes to the crystallisation of the discrete, although still evolving, body of law upholding indigenous peoples' rights. Uptake of the Court's jurisprudence by domestic tribunals further contributes to this state of dynamic interplay between sources and different fields of law.
\end{abstract}

\section{Introduction}

On 28 January 2016, the Inter-American Court of Human Rights (the Court) issued its judgment in the case of the Kaliña and Lokono Peoples v. Suriname. ${ }^{1}$ This case was first submitted to the Inter-American Commission on Human Rights (IACHR) in January 2007 by eight indigenous peoples' communities, collectively comprising the Kaliña and Lokono peoples of the Lower Marowijne River. The IACHR adopted a decision on the merits in July 2013 and, following Suriname's noncompliance with its recommended remedial measures, transmitted the case to the Court in January 2014. ${ }^{2}$ In its judgment, the Court held Suriname responsible for violations of the right to juridical personality, the right to collective property, political rights, and the right to

1. Kaliña and Lokono Peoples v. Suriname, IACTHR (2015) Series C, No. 309 (hereinafter Kaliña and Lokono Peoples).

2. Kaliña and Lokono Peoples v. Suriname, IACHR, Case 12.639, Report No. 79/13 (2013), available at: <www.oas.org/en/iachr/decisions/ court/12639FondoEn.pdf>. judicial protection, rights all guaranteed under the American Convention on Human Rights (ACHR). ${ }^{3}$

The Court found that it was 'an undisputed fact that the laws of Suriname do not recognize the possibility that the indigenous peoples may be constituted as legal persons and, consequently, they lack standing to hold collective property titles'. ${ }^{4}$ It further found that Suriname's laws do not provide any legal remedies for the protection of their collective property rights. ${ }^{5}$ These conclusions largely restated the findings in its Moimana Village v. Suriname and Saramaka People v. Suriname judgments. ${ }^{6}$ The Court further determined that a series of activities - bauxite mining, the acquisition of lands by third parties and the maintenance of nature reserves had resulted in additional violations. The Court's corresponding orders, wholly or partially, respond to the reparations requested by the Kaliña and Lokono and include a number of significant measures.

The Court, for example, ordered guarantees of non-repetition, requiring that Suriname adopts legislative and other measures to recognise the rights of all indigenous and tribal peoples subject to its jurisdiction, measures not initially requested by the complainants. ${ }^{7}$ Normally, such guarantees are employed to address structural issues affecting human rights beyond those of the named victims. ${ }^{8}$ In this regard, the structural nature of the defects in Suriname law and practice were repeatedly highlighted by the IACHR and the Kaliña and Loko-

Kaliña and Lokono Peoples, above n. 1, at 305

4. Id. at 50. See also UN Expert Mechanism on the Rights of Indigenous Peoples, Access to Justice in the Promotion and Protection of the Rights of Indigenous Peoples, A/HRC/24/50 (2013), at 20 (stating that '... the right to self-determination requires recognition of the legal standing of indigenous peoples as collectives, and of their representative institutions, to seek redress in appropriate forums. Moreover, in these cases, remedies must be collective').

5. Id., at 249 and 268

6. Moiwana Village v. Suriname, IACTHR (2005) Series C, No. 124; Saramaka People v. Suriname, IACTHR (2007) Series C, No. 172 (hereinafter Saramaka People).

7. Kaliña and Lokono Peoples, above n. 1, at 305.

8. See e.g. D.J. Schonsteiner, 'Dissuasive Measures and the "Society as a Whole:" A Working Theory of Reparations in the Inter-American Court of Human Rights', 23 American University International Law Review 127, 148-9 (2007) 
no in the proceedings before the Court. ${ }^{9}$ These issues likewise featured heavily in the 2015 review of Suriname by the UN Committee on the Elimination of Racial Discrimination. ${ }^{10}$ The Court was also well aware of Suriname's protracted non-compliance with its prior judgments in Moimana Village and Saramaka People, and its concerns in this regard were sharpened by Suriname's failure to persuade the Court that it had any intention of complying. ${ }^{11}$ The former UN Special Rapporteur on the Rights of Indigenous Peoples (UNSRIP) concluded that this lack of compliance constitutes a 'prolonged condition of international illegality'. ${ }^{12}$ In this light, the Court provided a simple explanation for the guarantees of non-repetition:

[i]n cases such as this one, in which repeated violations of the human rights of indigenous and tribal peoples have been committed, the guarantees of nonrepetition acquire greater relevance as a measure of reparation, so that similar acts are not repeated and also to contribute to prevention. ${ }^{13}$

The judgment also favourably clarifies or advances jurisprudence in some respects. Its treatment of the rights of indigenous peoples in relation to environmental protected areas, and associated international environmental law, is especially noteworthy. This had a major influence on two recent reports on these issues submitted to the UN Human Rights Council. ${ }^{14}$ The same is true for its repeated citation of the 2007 UN Declaration on the Rights of Indigenous Peoples (UNDRIP), in some cases reading its provisions into its interpretation of the

9. 'IACHR Takes Case involving Kaliña and Lokono Peoples v. Suriname to the Inter-American Court', IACHR Press Release, 4 February 2014 (explaining that there exists 'a structural problem area involving a lack of recognition in domestic law of the juridical personality and right to collective property...'), available at: <www.oas.org/en/iachr/media_ center/PReleases/2014/009.asp>.

10. CERD/C/SUR/CO/13-15, (2015), at 21 (observing that indigenous and tribal peoples suffer from 'Structural Discrimination') and; at 22 (recommending that Suriname take 'all necessary special measures to address the existing structural discrimination faced by indigenous and tribal peoples...').

11. Video of Hearing, Kaliña and Lokono Peoples, 4 February 2015, at 1:55 et seq., available at: <https://vimeo.com/album/3247192/video/ 118766033>, (where Judge García Sayán, 'echoed' by Judge Roberto Caldas, stated that: 'I must confess my frustration at not finding any response on the part of the State which would allow me to be optimistic that the decisions ... in this case are going to be fulfilled because whatever the Court decides is ultimately going to be left to the State to implement, and we are going to have a problem which is very similar to what we saw seven years ago with regard to Saramaka'. He sought assurances from Suriname so that the Court 'will actually have firm reason to believe that the State's statements are not simply a collection of assertions that are not grounded in reality...').

12. Report of the Special Rapporteur on the Rights of Indigenous Peoples, A/HRC/18/35/Add.7 (2011), at 11.

13. Kaliña and Lokono Peoples, above n. 1, at 300.

14. Report of the Special Rapporteur of the Human Rights Council on the Rights of Indigenous Peoples, A/71/229 (2016); and Report of the Special Rapporteur on the Issue of Human Rights Obligations Relating to the Enjoyment of a Safe, Clean, Healthy and Sustainable Environment, A/HRC/34/49 (2017). Agreeing with the Court, the Rapporteurs, at 28 and 59, respectively, underscore that respect for indigenous peoples' rights 'should be seen as complementary, rather than contradictory, to environmental protection'.
ACHR and reinforcing the view that various UNDRIP provisions restate existing law. ${ }^{15}$ Likewise, the Court's references to the UN Guiding Principles on Business and Human Rights ${ }^{16}$ are considered by some to have potentially enhanced the development of standards in relation to the private sector. ${ }^{17}$ One commentator, for instance, concludes that the Court's decision 'is an encouraging sign that the UNGPs might yet become more meaningful and less voluntary, and have a life beyond the "soft law" nursery which raised them'. ${ }^{18}$

Expert testimony was an important part of the evidence presented to the Court and clearly influenced some of its rulings. ${ }^{19}$ In cases involving indigenous peoples, anthropologists or historians are often called to give evidence about the specific situation of the claimants, and their testimony is typically cited to support the Court's factual findings ${ }^{20}$ and, sometimes, reparations. ${ }^{21}$ The Court may also allow or request testimony from experts on particular legal issues and it normally does so when confronted with issues for the first time or in a new context, or where more detailed consideration appears warranted. In Kaliña and Lokono, two experts testified about issues of law. Victoria Tauli-Corpuz, the UNSRIP, testified, inter alia, about the interrelations between human rights and international environmental

15. See e.g. M. Barelli, 'The Role of Soft Law in the International Legal System: The Case of the United Nations Declaration on the Rights of Indigenous Peoples', 58 International and Comparative Law Quarterly 957, at 966 (2009) (explaining that 'the strong relationship between the content of the Declaration and existing law should be recognized. The fact that the Declaration contains provisions that refer to rights and principles already recognized, or emerging, in the realm of international human rights, and, more specifically, within the indigenous rights regime, represents a first important indication of the legal significance of the instrument')

16. Kaliña and Lokono Peoples, above n. 1, at 224 (citing UN Guiding Principles on Business and Human Rights, Principle 1); and 225 (citing UN Doc. A/HRC/17/31, 18, concerning human rights due diligence by a business enterprise and stating that this 'indicates that businesses must respect the human rights of ... indigenous and tribal peoples, and pay special attention when such rights are violated').

17. A. Gonza, 'Integrating Business and Human Rights in the Inter-American Human Rights System', 1 Business and Human Rights Journal 357 (2016); and A. Mondragón, 'Corporate Impunity for Human Rights Violations in the Americas: The Inter-American System of Human Rights as an Opportunity for Victims to Achieve Justice', 57 Harvard International Law Journal 53, at 56 (2016) (explaining that "[t]his is the first case in which the Court "takes note" of the Guiding Principles on Business and Human Rights,' and, however, correctly observing that the Court has not used 'opportunities to develop specific state duties with regard to corporations acting in their jurisdiction. The recent judgment of the I/A Court in [Kaliña and Lokono Peoples] illustrates this lack of analysis').

18. C. Esdaile, 'Whilst We Wait for a Binding Treaty, Court Endorses UN Guiding Principles', Lexology, 7 March 2016, available at: <https:// www.lexology.com/library/detail.aspx?g=7ec1f0fb-405e-4e1d-b7c9 -94add086884a>

19. See e.g. Kaliña and Lokono Peoples, above n. 1, at 174-5.

20. See R. Price, Rainforest Warriors: Human Rights on Trial (2011) (providing an extensive analysis of Saramaka People v. Suriname from the perspective of an anthropologist expert witness); and S. Kirsch, Engaged Anthropology: Politics Beyond the Text (2018), Ch. 7 (discussing his role as an expert witness, by affidavit, in Kaliña and Lokono Peoples, above n. 1).

21. See e.g. G. Citroni and K. Quintana, 'Reparations for Indigenous Peoples in the Case Law of the Inter-American Court of Human Rights', in F. Lenzini (ed.), Reparations for Indigenous Peoples: International and Comparative Perspectives (2008). 
law. Jérémie Gilbert testified, inter alia, about restitution of lands, including in the context of environmental conservation. In their oral testimony, both experts highlighted various provisions of the UNDRIP.

This article looks primarily at how the Court's judgment in Kaliña and Lokono references or otherwise incorporates provisions of the UNDRIP. This includes an analysis of the extent to which the Court's reasoning and rulings track or diverge from the standards set therein. It concludes that there is substantial convergence: an unsurprising conclusion in some ways considering that the UNDRIP itself was the result of a process that mostly memorialised existing and emerging indigenous rights norms, including as derived from the Court's jurisprudence. Nonetheless, there is evidence that the UNDRIP itself is influencing the further development of standards in the inter-American system - and beyond, for example, given the influence of the Court's jurisprudence in the African system ${ }^{22}$ - blurring the distinction between 'soft' and 'binding' law, and intensifying the interrelationship between indigenous rights in universal and regional human rights law. ${ }^{23}$ This also illustrates, inter alia, the importance of strategic litigation as a means of further developing indigenous rights standards, including by elaborating on and amplifying UNDRIP provisions and their application. ${ }^{24}$ The latter may become even more relevant given the expansion of the mandate of the UN Expert Mechanism on the Rights of Indigenous Peoples: 'to achieve the ends of the Declaration through the promotion, protection and fulfilment of the rights of indigenous peoples;' and to '[p]repare an annual study on the status on the rights of indigenous peoples worldwide in the achievement of the ends of the Declaration...' ${ }^{25}$

\section{Kaliña and Lokono Peoples and UNDRIP}

\subsection{Citation, Coherence and Incorporation}

In its 2007 Saramaka People judgment, the Court was the first international human rights tribunal to specifically cite the UNDRIP, ${ }^{26}$ a move welcomed shortly thereafter by the UN Permanent Forum on Indigenous

22. See e.g. Endorois Welfare Council v. Kenya, African Commission on Human and Peoples' Rights, No. 276/2003 (2010) (extensively citing Saramaka People).

23. See e.g. M. Barelli, 'The Interplay Between Global and Regional Human Rights Systems in the Construction of the Indigenous Rights', 32 Human Rights Quarterly 951 (2010).

24. See also C. Baldwin and C. Morel, 'Using the United Nations Declaration on the Rights of Indigenous Peoples in Litigation', in S. Allen and A. Xanthaki (eds.), Reflections on the UN Declaration on the Rights of Indigenous Peoples (2011).

25. Human Rights Council, A/HRC/33/L.25, 26 September 2016, at 1 and 2(a).

26. Saramaka People, above n. 22, at 131 (quoting UNDRIP, Art. 32(2)). See also L. Rodriguez-Pinero, 'The Inter-American System and the UN Declaration on the Rights of Indigenous Peoples: Mutual Reinforcement', in S. Allen and A. Xanthaki (eds.), Reflections on the UN Declaration on the Rights of Indigenous Peoples (2011) (reviewing the influ-
Issues. ${ }^{27}$ While it has done so to some extent in other cases since then, most notably Sarayaku v. Ecuador ${ }^{28}$ in Kaliña and Lokono Peoples it extensively references, tracks and even incorporates provisions of the UNDRIP into its interpretation of state obligations in the ACHR. ${ }^{29}$ This attention may be attributed in part to widespread reference to the UNDRIP and interrelated law in pleadings submitted by the Kaliña and Lokono and the expert testimony rendered before the Court, whereas arguments submitted in prior cases focused especially on ILO Convention No. 169, an instrument in force for all but one of the respondent states. Irrespective, the Court's reliance on the UNDRIP fortifies already persuasive arguments about the legal stature of many of its provisions - in part based on their coherence with interpretations of binding instruments - and further concretises the body of law confirming and protecting indigenous peoples' rights. ${ }^{30}$ The same may be said for the (too numerous to cite here) explosion of references to and endorsements of the UNDRIP by UN treaty bodies and Special Procedures of the Human Rights Council. ${ }^{31}$ Some of them even call on states to 'comply' with the UNDRIP and incorporate it into domestic law, ${ }^{32}$ including, in one instance, Suriname. ${ }^{33}$ The majority view holds that the UNDRIP in toto is, at a bare minimum, an authoritative 'guide' by which to

ence of the UNDRIP, including in its draft form, in the inter-American system).

27. 'Permanent Forum Hails General Assembly Adoption of Indigenous Rights Declaration', available at: <www.un.org/News/Press/docs/2008/ hr4953.doc.htm>.

28. See e.g. Kichwa Indigenous People of Sarayaku v. Ecuador, IACTHR (2012) Series C, No. 245, 201, 215 and 217 (hereinafter Sarayaku).

29. See e.g. Kaliña and Lokono Peoples, above n. 1, at 139 (citing and quoting UNDRIP, Art. 26); 180 (quoting Arts. 18, 25 and 29 and citing Art. 23); 202 (quoting Arts. 18, and 32(2)); 221 (citing Art. 32(3)); 231 (citing Art. 12); 251(3) (citing the fifth preambular paragraph and Art. 2); 251(5) (citing Arts. 27 and 33(2)); 296 citing UNDRIP, Art. 29); Partially Dissenting Opinion of Judge Alberto Pérez Pérez (citing Arts. 18 and 32); and Joint Concurring Opinion of Judges Humberto Antonio Sierra Porto and Eduardo Ferrer MacGregor Poisot (citing Arts. 18, 29 and 32).

30. See e.g. M. Åhrén, Indigenous Peoples' Status in the International Legal System (2016), 103-7

31. See e.g. F. MacKay (ed.), Indigenous Peoples and United Nations Human Rights Bodies: A Compilation of UN Treaty Body Jurisprudence, Special Procedures of the Human Rights Council, and the Advice of the Expert Mechanism on the Rights of Indigenous Peoples, Vols. VI-VII (covering the years 2013-16), available at: <https://www. forestpeoples.org/en/legal-human-rights-human-rights-mechanisms-un -human-rights-system-guides-human-rights-mechanisms>

32. See e.g. E/C.12/UGA/CO/1 (2015), at 13 (recommending that Uganda includes 'recognition of indigenous peoples in the Constitution in line with the [UNDRIP]'); CRC/C/GAB/CO/2 (2016), at 61(a) (calling on Gabon to '[a]dopt a law for the protection of indigenous people based on the [UNDRIP]'); and CEDAW/C/BOL/CO/5-6 (2015), at 25(c) (recommending that Bolivia '[e]nsure[s] that indigenous women have access to education in compliance with the criteria enshrined in the [UNDRIP]').

33. CERD/C/SUR/CO/13-15, above n. 10, at 24 (reiterating 'its recommendation concerning the drawing up of a framework law on the rights of indigenous and tribal peoples', and 'that this framework law comply with the provisions of the United Nations Declaration on the Rights of Indigenous Peoples'). 
interpret state obligations under various human rights instruments. $^{34}$

The preceding is most clearly illustrated in the Court's treatment of property and participation rights pursuant to Articles 21 and 23 of the ACHR, respectively, in Kaliña and Lokono Peoples. The Court's reparations orders are also instructive. In its judgment, the Court reiterated its findings in Saramaka People that 'the domestic laws of Suriname do not recognize the [indigenous peoples'] right to communal property...', ${ }^{35}$ and that this right must be read together with the right to self-determination. ${ }^{36}$ The Court concluded that "the Kaliña and Lokono are protected by international human rights law which guarantees the right to the collective territory ...; [and] the State has the obligation to adopt special measures to recognize, respect, protect and guarantee' this right. ${ }^{37}$ Referring to its prior jurisprudence, ${ }^{38}$ it explained, inter alia, that the state must: 'ensure the effective ownership of the indigenous peoples and refrain from taking steps that could lead to State agents, or third parties acting with their acquiescence or tolerance, adversely affecting the existence, value, use or enjoyment of their territory'; 'ensure the right of the indigenous peoples to control and to own their territory without any type of outside interference by third parties'; and 'ensure the right of the indigenous and tribal peoples to control and to use their territory and natural resources' ${ }^{39}$

34. See e.g. CERD/C/USA/CO/6 (2008), at 29 (recommending that the USA employs the UNDRIP 'as a guide to interpret [its'] ... obligations ... relating to indigenous peoples'); and Committee on the Rights of the Child, General Recommendation No. 11, Indigenous Children and their Rights under the Convention (2009), 82.

35. Kaliña and Lokono Peoples, above n. 1, at 122.

36. Id. (further explaining that by virtue of the right to self-determination, indigenous peoples may 'freely pursue their economic, social and cultural development' and may 'freely dispose of their natural wealth and resources' to ensure that they are not 'deprived of [their] own means of subsistence;') and, at 123, (that this 'supports an interpretation of Article 21 of the American Convention that requires recognition of the right of the members of indigenous and tribal peoples to freely determine and enjoy their own social, cultural and economic development, which includes the right to enjoy their particular spiritual relationship with the territory they have traditionally used and occupied'). See also P. Macklem, The Sovereignty of Human Rights (2015), at 48 (explaining that 'indigenous peoples have rights of internal self-determination, which entitle them to extensive protection associated with their identities, cultures, territories, and forms of governance').

37. Id., at 125 .

38. Id., at 131-2.

39. Id., at 132 (citing Mayagna (Sumo) Awas Tingni Community Case v. Nicaragua, IACTHR (2001) Series C, No. 79; Saramaka People, above n. 22; and Sarayaku, above n. 28) (footnotes omitted).

40. The IACHR and the Court have previously equated control over territory with indigenous peoples' survival, development and the pursuit of their aspirations. Mary and Carrie Dann v. United States of America, IACHR (2002), Case 11.140, Report 75/02, at 128 (observing that 'continued utilization of traditional collective systems for the control and use of territory are in many instances essential to ... the survival of indigenous peoples'); and Yakye Axa v. Paraguay, IACTHR (2005) Series C, No. 125, at 146 (observing that indigenous territorial rights encompass a broader and different concept that relates to the collective right to survival as an organized people, with control over their habitat
The Court first emphasised the 'control' aspect of indigenous property rights ${ }^{40}$ in Saramaka People, ${ }^{41}$ relating it to the territorial/resource sovereignty aspect of the right to self-determination. ${ }^{42}$ It includes various aspects of self-government, ${ }^{43}$ including indigenous peoples' rights to internally regulate and manage territory and to freely determine and enjoy their own social, cultural and economic development, all through their own institutions and procedures. ${ }^{44}$ UNDRIP, Article 26(2), also recognises this right, providing in pertinent part that 'Indigenous peoples have the right to own, use, develop and control' their traditional lands, territories and resources. Note in this context also that in Chitay Nech, the Court observed that the direct representation of indigenous peoples, through their mandated representatives and institutions, is 'a necessary prerequisite' for the exercise of their right to self-determination... , 45 The Court further explained in Kalina and Lokono Peoples that, 'based on the principle of legal certainty', indigenous peoples' land rights 'must be formalized by the adoption of the administrative and legislative measures required to create an effective mechanism for delimitation, demarcation and the granting of titles that

as a necessary condition for reproduction of their culture, for their own development and to carry out their life aspirations').

41. Saramaka People, above n. 22, at 115 (observing that Suriname's 'legal framework ... does not guarantee the right to effectively control their territory without outside interference'); and, at 194 (ordering that recognition of the Saramaka people's 'right to manage, distribute, and effectively control such territory, in accordance with their customary laws and traditional collective land tenure system'); Saramaka People v. Suriname, IACTHR (2008) Series C, No. 185, 48-50; accord Apirana Mahuika et al. v. New Zealand, (Communication No. 547/1993), CCPR/C/70/D/547/1993 (2000), at 9.7 (explaining that a conjunctive reading of Arts. 1 and 27 of the Covenant implies that indigenous peoples have a right to enjoy 'effective possession' of and 'effective control' over natural resources).

42. Since 2013, the Committee on Economic, Social and Cultural Rights routinely addresses indigenous territorial and associated rights under Art. 1 of the Covenant. See e.g. E/C.12/PRY/CO/4 (2015), at 6 (expressing concern that Paraguay 'has not yet legally recognized the right of indigenous peoples to dispose freely of their natural wealth and resources or put in place an effective mechanism to enable them to claim their ancestral lands (art. 1)'). Identical or similar language is found in 2015-16 reviews of Chile, Thailand, Uganda, Venezuela, Guyana, Kenya, Namibia, Canada, Honduras, Sweden, and Costa Rica.

43. Kaliña and Lokono Peoples, above n. 1, at 124. See also Kuna Indigenous Peoples of Madungandi and Embera Indigenous People of Bayano v. Panama, IACHR (2012), Case 12.354, Report 125/12, at 259 (attributing positive value to the establishment of a legal mechanism for recognition of collective property rights and stating that it understands that the mechanism cannot exclude rights of indigenous peoples that are associated mainly with the right to self-government according to their traditional uses and customs...').

44. See e.g. UNDRIP, Arts. 3, 4, 5, 20(1), 23, 26(2) and 32(1).

45. Chitay Nech v. Guatemala, IACTHR (2010) Series C, No. 212, at 113 (also observing, at 115, that indigenous leaders 'exercise their charge by mandate or designation and in representation of a community. This duality is both the right of the individual to exercise the mandate or designation (direct participation) as well as the right of the community to be represented. In this sense, the violation of the first reverberates in the damage of the other right'). See also CERD/C/CRI/CO/19-22 (2015), at 25 (expressing concern that local government bodies in Costa Rica 'have supplanted indigenous peoples' own institutions in their relations with the State...;' and recommending 'that indigenous peoples' authorities and representative institutions be recognized in a manner consistent with their right to self-determination in matters relating to their internal and local affairs'). 
recognizes these rights in the practice'. ${ }^{46}$ It elaborated again, stating that indigenous peoples' right to property 'includes full guarantees over the territories they have traditionally owned, occupied and used in order to ensure their particular way of life, and their subsistence, traditions, culture, and development as peoples'. ${ }^{47}$

The language 'full guarantees over the territories they have traditionally owned, occupied and used', should be understood in the following way. Citing, tracking the structure of, and expounding on the general principles employed in the UNDRIP ${ }^{48}$ the Court ruled that the state is obligated to: ${ }^{49}$

1. delimit the territory traditionally owned by the Kaliña and Lokono, ${ }^{50}$ which, 'in turn, implies establishing borders and boundaries, as well as its size'. ${ }^{51}$ The term 'traditionally owned' should be understood in relation to their traditional tenure system and related customary laws, which must be respected; ${ }^{52}$ as must their 'distinctive spiritual relationship' with their 'lands, territories, waters and coastal seas and other resources' 53 and, more broadly, the profound relationship between indigenous lands and cultural identity and integrity ${ }^{54}$

2. those areas of territory traditionally owned which are currently possessed by them automatically become subject to their ownership, control and other rights; ${ }^{55}$

3 . those areas within the delimited territory not currently possessed (e.g. in the possession of a third party, nature reserves or concessions), but nonetheless sub-

46. Kaliña and Lokono Peoples, above n. 1, at 133.

47. Id. at 139

48. Id., footnote 178, where the Court cites UNDRIP, Art. 26, and states that 'Similarly, [that article] recognizes the right to lands, territories and resources which they have traditionally owned, occupied or otherwise used or acquired, as well as the right to own, use, develop and control these lands; thus, States must give legal recognition and protection to these lands, respecting the customs, traditions and land tenure systems of the indigenous peoples concerned'. See also Yakye Axa v. Paraguay, IACTHR (2006) Series C, No. 142, at 34 (containing a similar process).

49. Id., at 125 ('the State has the obligation to adopt special measures to recognize, respect, protect and guarantee ... the right to communal ownership of this territory').

50. UNDRIP, Art. 26(1), providing that 'Indigenous peoples have the right to the lands, territories and resources which they have traditionally owned, occupied or otherwise used or acquired'.

51. Yakye Axa v. Paraguay, above n. 48 , at 34.

52. Mayagna (Sumo) Awas Tingni, above n. 39, 164 ('the State must adopt the legislative, administrative, and any other measures required to create an effective mechanism for delimitation, demarcation, and titling of the property of indigenous communities, in accordance with their customary law, values, customs and mores').

53. UNDRIP, Art. 25; accord Kaliña and Lokono Peoples, above n. 1, 124; and Saramaka People, above n. 22, at 95.

54. See e.g. Rio Negro Massacres v. Guatemala, IACTHR (2012), Series C, No. 250, at 160 (where the Court explained that it 'has already indicated that the special relationship of the indigenous peoples with their ancestral lands is not merely because they constitute their main means of subsistence, but also because they are an integral part of their cosmovision, religious beliefs and, consequently, their cultural identity or integrity, which is a fundamental and collect right of the indigenous communities that must be respected...') (footnotes omitted).

55. UNDRIP, Art. 26(2), providing that 'Indigenous peoples have the right to own, use, develop and control the lands, territories and resources that they possess by reason of traditional ownership or other traditional occupation or use, as well as those which they have otherwise acquired' (emphasis added) ject to the Kaliña and Lokono's property rights and associated guarantees, require formal assessment ${ }^{56}-\mathrm{a}$ weighing and balancing of rights or interests by the state $^{57}$ - to determine if they should be returned to the Kaliña and Lokono (restitution) or whether an alternative remedy is required (e.g. compensation, benefit sharing, provision of alternative lands, or revocation of concessions); ${ }^{58}$ and

4. the state must legally recognise, demarcate and title the full extent of the lands, territory and resources ${ }^{59}$ that result from this process, in which the indigenous peoples must participate, and further guarantee the Kaliña and Lokono the 'full and equal exercise ${ }^{90}$ of their right to these lands, and their effective control over and use and enjoyment ${ }^{61}$ of the same. ${ }^{62}$

UNDRIP was again employed explicitly by the Court in relation to the political participation rights guaranteed by Article 23 of the ACHR. ${ }^{63}$ In particular, it directly read Article 18 of the UNDRIP into its interpretation of Article 23, collectivising the right as it applies to indigenous peoples in the process. Noting the relationship with collective property rights, the Court ruled that the state must establish mechanisms for effective participation: ' $\mathrm{t}$ ]his is not only a matter of public interest, but

56. Id., Art. 27 ('States shall establish and implement, in conjunction with indigenous peoples concerned, a fair, independent, impartial, open and transparent process, giving due recognition to indigenous peoples' laws, traditions, customs and land tenure systems, to recognize and adjudicate the rights of indigenous peoples pertaining to their lands, territories and resources, including those which were traditionally owned or otherwise occupied or used. Indigenous peoples shall have the right to participate in this process').

57. Kaliña and Lokono Peoples, above n. 1, at 155 (where the Court holds that this involves assessing, on a case by case basis, 'the legality, necessity, proportionality and attainment of a legitimate objective in a democratic society ... in order to restrict the right to property, on the one hand, or the right to traditional lands, on the other, without the restriction of the latter preventing the survival of the members of the indigenous communities as a people').

58. UNDRIP, Art. 28 (providing that '(1) Indigenous peoples have the right to redress, by means that can include restitution or, when this is not possible, just, fair and equitable compensation, for the lands, territories and resources which they have traditionally owned or otherwise occupied or used, and which have been confiscated, taken, occupied, used or damaged without their free, prior and informed consent. (2) Unless otherwise freely agreed upon by the peoples concerned, compensation shall take the form of lands, territories and resources equal in quality, size and legal status or of monetary compensation or other appropriate redress').

59. See e.g. Sarayaku, above n. 28, at 148 (stating that 'the right to use and enjoy the territory would be meaningless for indigenous and tribal communities if that right were not connected to the protection of natural resources in the territory').

60. Id., at 171

61. Kaliña and Lokono Peoples, above n. 1, at 136. See also Kuna and Emberá Indigenous Peoples v. Panama. IACTHR (2014) Series C, No. 284 , at 142 (stating that 'by granting these lands to indigenous peoples, the State acquires the duty of ensuring the effective enjoyment of the right to property')

62. UNDRIP, Art. 26(3), providing that 'States shall give legal recognition and protection to these lands, territories and resources. Such recognition shall be conducted with due respect to the customs, traditions and land tenure systems of the indigenous peoples concerned'.

63. Art. 23 of the ACHR provides, in pertinent, part that '[e]very citizen shall enjoy the following rights and opportunities: (a) to take part in the conduct of public affairs...'. 
also forms part of the exercise of [indigenous peoples'] right to take part in any decision-making on matters that affect their interests, in accordance with their own procedures and institutions...' ${ }^{64}$ This was applied in relation to the exploitation of resources and conservation of the environment via nature reserves. ${ }^{65}$ It should be noted that this is not the first occasion that the Court has read so-called soft law into its interpretation of the ACHR's guarantees. In Moimana Village, for instance, the Court essentially read many of the UN Guiding Principles on Internal Displacement ${ }^{66}$ into its interpretation of state obligations under Article 22 of the ACHR (on freedom of movement) ${ }^{67}$

With respect to the nature reserves in the territory of the Kaliña and Lokono, the Court further ruled that it is necessary to:

recognize the right of the indigenous peoples to use their own institutions and representatives to manage, administer and protect their traditional territories ... [and;] seek agreements between the respective communities and the conservation agencies that establish the management, the commitments, the responsibilities, and the purposes of the area.... ${ }^{68}$

The Court also cited UNDRIP, Article 12, to hold that, in the nature reserves, states should 'accede to [indigenous peoples'] traditional health system and other sociocultural functions, and preserve their way of life, customs and language, as well as to accede to, maintain and protect their religious and cultural sites'. ${ }^{69}$ Additionally, traditional practices that 'contribute to the sustainable care and protection of the environment should be maintained, protected and promoted;' it is, therefore, 'pertinent to support the indigenous peoples' knowledge, institutions, practices, strategies and management plans related to conservation' ${ }^{70}$ This is consistent with UNDRIP, Article 29(1), which provides, in part, that

64. Kaliña and Lokono Peoples, above n. 1, at 203. UNDRIP, Art. 18 provides that 'Indigenous peoples have the right to participate in decisionmaking in matters which would affect their rights, through representatives chosen by themselves in accordance with their own procedures, as well as to maintain and develop their own indigenous decision-making institutions'.

65. Id., at 196 (quoting UNDRIP, Art. 18, and ruling that 'the participation of the indigenous communities in the conservation of the environment is not only a matter of public interest, but also part of the exercise of their right as indigenous peoples "to participate in decision-making in matters which would affect their rights, [...] in accordance with their own procedures and [...] institutions"').

66. E/CN.4/1998/53/Add.2 (1998).

67. Moiwana Village v. Suriname, above n. 6, at 111 (holding that the many of the Guiding Principles 'illuminate the reach and content of Article $22 \ldots$ in the context of forced displacement' and emphasizing that 'States are under a particular obligation to protect against the displacement of indigenous peoples ... and other groups with a special dependency on and attachment to their lands').

68. Kaliña and Lokono Peoples, above n. 1, at footnote 230.

69. Id., at footnote 231 (also citing Decisions adopted by the Conference of the Parties to the Convention on Biological Diversity at its twelfth meeting, e.g. Decision XII/12, 8-9). See also Sarayaku, above n. 28, at 146-7 (highlighting the relationship between land rights and 'traditional 70. Id. indigenous peoples have a right to conservation and protection of the environment and the productive capacity of their lands, and states 'shall establish and implement assistance programmes' to support the same.

Locating indigenous participation rights in Article 23 of ACHR is not new in the inter-American human rights system. ${ }^{71}$ Nonetheless, two of the judges considered that Kaliña and Lokono Peoples represented an innovation in its case law in this respect, even if, to observers at least, the significance is not readily apparent. ${ }^{72}$ Previously, the Court had only narrowly applied that article to indigenous participation (in Nicaragua's electoral system and, on an individual basis, to the forced disappearance of a prominent indigenous leader in Guatemala), ${ }^{73}$ and it had explicitly refused to apply it to indigenous landrelated issues on one prior occasion. ${ }^{74}$ Instead, the Court has repeatedly grounded participation rights in the right to property, a right that is subject to an express and broad subordination clause when the state asserts a public interest. ${ }^{75}$ It mitigated this somewhat in Saramaka People and its progeny ${ }^{76}$ by requiring, inter alia, effective participation, and consent in some circumstances, in relation to proposed subordinations under Article 21, so it is unlikely that this explains where the innovation lies. ${ }^{77}$ Article 23, on the other hand, allows for the regulation, not subordination, of political rights on specified grounds, which do not include the public interest as such. ${ }^{78}$ This may be one reason why Judge Pérez Pérez deemed it to have a 'very different meaning and content' from the participation rights under Article 21. ${ }^{79}$

71. See e.g. IACHR, Report on the Situation of Human Rights in Ecuador. OEA/Ser.L/V/II.96, Doc. 10 rev. 1 (1997).

72. Joint Concurring Opinion, Sierra Porto and Ferrer Mac-Gregor Poisot, above n. 29, at 21 (observing that the reference to Art. 23 and the right to effective participation more generally constitute 'developments in the Court's case law...').

73. Yatama v. Nicaragua, IACTHR (2005) Series C, No. 127; and Chitay Nech v. Guatemala, above n. 45.

74. Sarayaku, above n. 28 , at 230 (declining to address an alleged violation of Art. 23 on the basis that 'the facts have been sufficiently analyzed and the violations conceptualized .... in the terms of Article 21 of the Convention...')

75. Art. 21 provides, in part, that "1. Everyone has the right to the use and enjoyment of his property. The law may subordinate such use and enjoyment to the interest of society. 2. No one shall be deprived of his property except upon payment of just compensation, for reasons of public utility or social interest, and in the cases and according to the forms established by law'.

76. See T. Antkowiak, 'Rights, Resources and Rhetoric: Indigenous Peoples and the Inter-American Court', 35 University of Pennsylvania Journal of International Law 113 (2013) (commenting on, inter alia, the limitations of the right to property as a guarantee for the complex of indigenous rights addressed by the Court, particularly in light of the wide powers to limit property rights, and concluding that, while the Court has attempted to mitigate this by creating special safeguards for indigenous lands and resources, these safeguards have proved to be inadequate).

77. Saramaka People, above n. 22, at 129-34.

78. Art. 23(2) provides that 'The law may regulate the exercise of the rights and opportunities referred to in the preceding paragraph only on the basis of age, nationality, residence, language, education, civil and mental capacity, or sentencing by a competent court in criminal proceedings'.

79. Partially Dissenting Opinion of Judge Pérez Pérez, above n. 29, at 20(g). 
A more likely explanation, however, lies in both the Court's prior case law and its adaptation in Kaliña and Lokono. First, in Yakye Axa, the Court held that respect for indigenous peoples' rights is a vitally important and countervailing - public interest in its own right. ${ }^{80}$ In Kaliña and Lokono, it went a step further, ruling that effective participation by indigenous peoples in decision-making is itself integral to establishing the legitimacy of a public interest declaration as well as a right that must be respected in general. ${ }^{81}$ It is important to note that this line of analysis is not confined only to international human rights bodies. ${ }^{82}$ For example, the Canadian Supreme Court observed in relation to lack of consultation around the granting of oil and gas permits that a 'project authorization that breaches the constitutionally protected rights of Indigenous peoples cannot serve the public interest'. ${ }^{83}$ It would appear, therefore, that the Court is holding that states must ensure indigenous participation and fully account for the separate and countervailing public interest of respecting indigenous peoples' rights from the outset, and as part of determining the public interest per se, and the failure to do so may invalidate any asserted public interest justification. Second, locating participation rights in Article 23 broadens their scope and they would apply not only in relation to activities that may affect or subordinate property rights, but to any vested right. This builds on Sarayaku, where the Court made clear that participation rights extend beyond matters that only affect indigenous lands; they also adhere to rights essential to their 'survival as a people', and the state must 'ensure that the rights of indigenous peoples are not ignored in any other activity or agreement reached with private individuals, or in the context of decisions of the public authorities that would affect their rights and interests' ${ }^{84}$ This includes the adoption of legislation, in which case indigenous peoples 'must be consulted in advance during all stages of the process of producing the legislation, and these consultations must not be restricted to proposals' ${ }^{85}$ This is partly consistent with UNDRIP, Article 19 , but omits its reference to consultation 'in order to obtain their free, prior and informed consent' prior to adopting and implementing legislative or administrative measures. Grounding participation rights in Article 23 would thus appear to be a more generalised approach. It is consistent with UNDRIP, Article 18, read into ACHR, Article 23, by the Court, while the effective participation safeguard retained in Article 21 reflects the

80. Yakye Axa v. Paraguay, above n. 40, at 148; accord Kaliña and Lokono Peoples, above n. 1, at 196.

81. Kaliña and Lokono Peoples, above n. 1, 196. See also Garífuna Community of Punta Piedra v. Honduras, IACTHR (2015) Series C, No. 304, 168-73 (finding violations of property and participation rights in connection with the establishment of a protected area).

82. See e.g. Endorois Welfare Council v. Kenya, above n. 22, at 212 (observing that 'the 'public interest' test is met with a much higher threshold in the case of encroachment of indigenous land rather than individual private property')

83. Clyde River (Hamlet) v. Petroleum Geo-Services [2017] SCC 40, at 70.

84. Sarayaku, above n. 28 , at 167.

85. Id., at 181 . heightened attention required when indigenous lands and resources may be affected, as provided by UNDRIP, Article 32(2). ${ }^{86}$

Last but not least, the Court's progressive jurisprudence on reparations in the indigenous context deserves mention. In general, the remedies ordered by the Court display an unprecedented sensitivity to indigenous peoples' perspectives and a willingness to creatively interpret the ACHR to protect the collective rights of indigenous peoples. ${ }^{87}$ This includes the collective dimension of harm suffered, both moral and material, ${ }^{88}$ and corresponding measures of redress. ${ }^{89}$ It also includes the identification of the victim(s) in collective terms; for instance, in the case under discussion, the Court 'considers the Kaliña and Lokono peoples and their members to be the injured party' ${ }^{90}$ Article 40 of the UNDRIP provides in this regard that indigenous people have the right to 'effective remedies for all infringements of their individual and collective rights', which shall 'give due consideration to the[ir] customs, traditions, rules and legal systems...' This general provision is complemented by specific reparations language found in various other articles (e.g. Articles 8, 12, 13 and 28). As noted above in the context of ACHR, Articles 21 and 23, the Court's approach to reparations is both consonant with the UNDRIP and adds significant flesh to the bare bones of its principles.

Prefacing its extensive reparations orders, ${ }^{91}$ the Court explained in Kaliña and Lokono Peoples that 'reparation should help strengthen the cultural identity' of the indigenous peoples, 'guaranteeing the control of their own institutions, cultures, traditions and territories in order to contribute to their development in keeping with their life projects, and present and future needs' ${ }^{92}$ Consequently, 'the measures of reparation granted should provide effective mechanisms, in keeping with their specific ethnic perspective, that permit them to define their priorities as regards their development and evolution as a people'. ${ }^{93}$ It also quoted UNDRIP, Arti-

86. See also Kaliña and Lokono Peoples, above n. 1, at 305(d) (ordering the State to establish effective mechanisms to guarantee effective participation ... in any project, investment, nature reserve or activity that could have an impact on their territory').

87. The Court, for instance, has repeatedly recognized the 'importance of taking into account certain aspects of the customs of the indigenous peoples of the Americas for purposes of application of the American Convention on Human Rights'. See e.g. Bamaca Velasquez v. Guatemala, IACTHR (2000) Series C, No 70, at 81; Mayagna (Sumo) Awas Tingni v. Nicaragua, above n. 39, at 149; Aloeboetoe et al. v. Suriname, IACTHR (1993) Series C, No 15, at 62; and Yakye Axa v. Paraguay, above n. 48 , at 63.

88. See e.g. Plan de Sánchez Massacre v. Guatemala, IACTHR (2004) Series C, No 105, at 86 (observing that the proven facts demonstrated that the Achí Mayan people's identity and values were seriously affected and, therefore, 'a significant component of the remedy should be reparations to the communities as a whole'); and Moiwana Village v. Suriname, above n. 6, at 201 (explaining that reparations 'have special significance ... given the extreme gravity of the facts and the collective nature of the damages suffered')

89. See e.g. Citroni and Quintana, above n. 21, at 319.

90. Kaliña and Lokono Peoples, above n. 1, at 273.

91. Id., 273-316.

92. Id., at 272

93. Id. 
cle 29(1), in its order requiring the establishment of a 'development fund'. ${ }^{94}$ This development fund is to serve

... as compensation for the pecuniary and non-pecuniary damage suffered by the Kaliña and Lokono, including 'harm to extremely representative values ... that have an impact on their cultural identity and on the cultural heritage to be transmitted to future generations.... 95

In the same vein, in Saramaka People, the Court identified the absence of effective domestic remedies as a key factor in awarding the Saramaka compensation for moral damages. It stated that the evidence demonstrates

... the suffering and distress that the members of the Saramaka people have endured as a result of the long and ongoing struggle for the legal recognition of their right to the territory they have traditionally used and occupied for centuries ... as well as their frustration with a domestic legal system that does not protect them against violations of said right ... all of which constitutes a denigration of their basic cultural and spiritual values. ${ }^{96}$

Likewise, in Moimana Village, the Court identified the community's forced displacement and prolonged separation from its traditional lands as one of the three bases for finding that Suriname had violated the right to mental and moral integrity (ACHR, Article 5). ${ }^{97}$ This figured prominently in the Court's determination of moral and material damages, ${ }^{98}$ and the Court presumed material harm, inter alia, because 'their ability to practice their customary means of subsistence and livelihood has been drastically limited'. ${ }^{99}$

\subsection{Concerns and Divergence: Survival and Consent}

The IACHR and IACTHR's jurisprudence ${ }^{100}$ affirms that indigenous lands are fundamental to indigenous peoples' cultural integrity and survival. ${ }^{101}$ This juris-

94. Id., at 296.

95. Id., at 295.

96. Saramaka People, above n. 22, at 200.

97. Moiwana Village v. Suriname, above n. 6, at 101, 102-3.

98. See also Sawhoyamaxa Indigenous Community v. Paraguay, IACTHR (2006), Series C, No. 146 (on the relevance of territorial rights to immaterial damages).

99. Moiwana Village v. Suriname, above n. 6, at 186-7.

100. See e.g. Xákmok Kásek Indigenous Community v. Paraguay, IACTHR (2010) Series C, No. 214, at 157; and IACHR, Indigenous Peoples, Afro-Descendent Communities, and Natural Resources: Human Rights Protection in the Context of Extraction, Exploitation, and Development Activities, OEA/Ser.L/V/II., Doc. 47/15 (2015).

101. See e.g. Sarayaku, above n. 28, at 146 (explaining that 'the protection of the territories ... also stems from the need to guarantee the security and continuity of their control and use of natural resources, which in turn allows them to maintain their lifestyle. This connection between territory and natural resources ... is necessary for their physical and cultural survival and the development and continuation of their worldview...'); and Río Negro Massacres v. Guatemala, above n. 54, at 177 (stating that its consistent case law on indigenous matters 'has recognized that the relationship of the indigenous peoples with the land is prudence additionally holds that certain restrictions on or interferences with their property and associated rights may be either 'impermissible'102 or subject to indigenous peoples' free, prior and informed consent, irrespective of any asserted public interest. ${ }^{103}$ The same is also the case, inter alia, in the jurisprudence of the Human Rights Committee. ${ }^{104}$

These considerations often provoke strong, negative reactions from states, which assert that this grants indigenous peoples a right to halt national development projects or even, as Suriname protested in Kaliña and Lokono, to undermine the democratic will of the people of the state. Nonetheless, the Court and other authorities have recognised that majorities cannot simply override the rights of minorities and indigenous peoples, even if they do so via legislation that enjoys widespread public support. For example, in Gelman v. Uruguay - concerning a broadly supported 'amnesty' law - the Court explained that 'the protection of human rights constitutes an impassable limit to the rule of the majority...' ${ }^{105}$ There is also recognition of the majoritarian biases inherent in the public interest doctrine. ${ }^{106}$

This basic limit is repeatedly referenced in the Court's indigenous jurisprudence, which explicates that stateinitiated or authorised projects and investments ${ }^{107}$ 'cannot negate the very survival of the members of the indigenous and tribal peoples'. ${ }^{108}$ In Saramaka and progeny, ${ }^{109}$ the term 'survival' is defined to mean indig-

essential for maintaining their cultural structures and for their ethnic and material survival...').

102. Saramaka People, above n. 22, at 128 (the State may restrict the Saramakas' right to use and enjoy lands and resources 'only when such restriction complies with the aforementioned requirements and, additionally, when it does not deny their survival as a tribal people').

103. Id., 134

104. See e.g. CCPR/CO/69/AUS (2000), at 10-11; accord, Bernard Ominayak, Chief of the Lubicon Lake Band vs. Canada, A/45/40, vol. 2 (1990); Apirana Mahuika, above n. 41; and Angela Poma Poma v. Peru, CCPR/C/95/D/1457/2006 (2009).

105. IACTHR (2011) Series C, No. 221, at 239

106. See e.g. CERD/C/IDN/CO/3 (2007), at 17 (observing that the rights of indigenous peoples have been compromised 'due to the interpretations adopted by the State party of national interest, modernization and economic and social development;' and recommending that Indonesia ensure that these concepts 'are defined in a participatory way, ... and are not used as a justification to override the rights of indigenous peoples'); and Report of the Special Rapporteur in the Field of Cultural Rights, A/70/279 (2015), 44 (referring to UNDRIP, Art. 46(2) - containing the grounds for limitations on rights - and concluding that such 'limitations can be problematic, however, if they are justified by reference to the interest of a mainstream society that otherwise does not recognize indigenous interests. In such cases, limitations can be misused to the detriment of indigenous communities').

107. Saramaka People, above n. 22, footnote 127 (defining 'development or investment plan' to mean 'any proposed activity that may affect the integrity of the lands and natural resources within the territory of the Saramaka people, particularly any proposal to grant logging or mining concessions').

108. Id. at 128; accord Angela Poma Poma v. Peru, above n. 104, at 7.6 (States parties 'must respect the principle of proportionality so as not to endanger the very survival of the community and its members').

109. See e.g. Garífuna Community of Punta Piedra v. Honduras, above n. 81, 167. See also Río Negro Massacres v. Guatemala, above n. 54, at 160; Moiwana Village v. Suriname, above n. 6, at 101, 102-3 (observing that: 'in order for the culture to preserve its very identity and integrity, [indigenous and tribal peoples] ... must maintain a fluid and multi- 
enous and tribal peoples' 'ability to "preserve, protect and guarantee the special relationship that they have with their territory", so that "they may continue living their traditional way of life, and that their distinct cultural identity, social structure, economic system, customs, beliefs and traditions are respected, guaranteed and protected"'.110 Additionally, the Court has ruled that states must assess the 'cumulative impact of existing and proposed projects' because this allows for 'a more accurate assessment on whether the individual or cumulative effects of existing or future activities could jeopardize the survival of indigenous or tribal people' ${ }^{111}$ The Court's above-stated jurisprudence is largely consistent with UNDRIP, Article 8, which, in connection with the right 'not to be subjected to forced assimilation or destruction of their culture', provides that states shall effectively prevent and provide redress for: '(a) Any action which has the aim or effect of depriving [indigenous peoples] of their integrity as distinct peoples, or of their cultural values or ethnic identities; [and] (b) [a]ny action which has the aim or effect of dispossessing them of their lands, territories or resources...'. Other provisions are also directly implicated (e.g. UNDRIP, Articles 11-13, 20, 23-25, 31, and 32(1)). As many interventions on indigenous lands also involve constructive removal from the land - as opposed to relocation via a formal process - Article 10 is also relevant, requiring that no relocation shall take place without free, prior and informed consent. Likewise, the UN Special Rapporteur on adequate housing identified UNDRIP, Article $7,{ }^{112}$ as a 'rich source for understanding the right to life and the right to adequate housing in international human rights law'. ${ }^{113}$ She further observed that the 'development and application of these rights has the potential to enhance the understanding of the social dimensions of the right to life and the interplay between the collective and individual dimensions of that right; it may also prompt a response to violations of rights to lands, territories or resources'. ${ }^{114}$ Unfortunately, no further explanation was provided about this premise or the interplay between the collective and individual dimensions of the right.

dimensional relationship with their ancestral lands'); and Yakye Axa v. Paraguay, above n. 40, at 146, (where the Court observes that 'indigenous territorial rights encompass a broader and different concept that relates to the collective right to survival as an organized people, with control over their habitat as a necessary condition for reproduction of their culture, for their own development and to carry out their life aspirations').

110. Saramaka People, above n. 22, 129-34 and; Saramaka People v. Suriname, above n. 41, at 37.

111. Saramaka People, above n. 22, at 41

112. UNDRIP, Art. 7, reads: '1. Indigenous individuals have the rights to life, physical and mental integrity, liberty and security of person. 2. Indigenous peoples have the collective right to live in freedom, peace and security as distinct peoples and shall not be subjected to any act of genocide or any other act of violence, including forcibly removing children of the group to another group'

113. Adequate Housing as a Component of the Right to an Adequate Standard of Living and on the Right to Non-Discrimination in this Context, $\mathrm{A} / 71 / 310(2016)$, at 56

114. Id
As a more general point, these and other standards recognise that effective guarantees for indigenous peoples' traditionally owned territories, including the right to control internal affairs and participate in external activities affecting them through their own institutions, underpin indigenous peoples' identity, integrity and survival. There is therefore a complex of interdependent human rights ${ }^{115}$ converging on and inherent to indigenous peoples' various relationships with their traditional lands and territories as well as their interrelated status as self-determining entities, all of which necessitates a high standard of affirmative protection. ${ }^{116}$

These issues were very relevant in Kaliña and Lokono given the scale and cumulative impact of the nature reserves, mining and logging operations, and individual titles, which cumulatively affect the vast majority of their territory. The Kaliña and Lokono peoples are severely restricted in and, in some cases, denied their ability to preserve their relationships with their territory and to maintain their traditional way of life in the vast majority thereof. This even extends to the core residential areas of their villages, which have been issued to and fenced-off by third parties for use as vacation homes! In its judgment, the Court determined that the proven violations had resulted in 'harm to extremely representative values of the [Kaliña and Lokono] ... that have an impact on their cultural identity and on the cultural heritage to be transmitted to future generations'. ${ }^{117}$ It observed more specifically that 'the extraction of bauxite ... resulted in serious damage to the environment and to the natural resources necessary for [their] survival and development', 118 and 'the negative effects have continued over time, thus affecting the traditional territory and the means of survival of the members of these peoples'. ${ }^{119}$ During the Court's on-site visit in August 2015 it saw for itself that 'the [mined] area had clearly been

115. See H. Quane, 'A Further Dimension to the Interdependence and Indivisibility of Human Rights? Recent Developments Concerning the Rights of Indigenous Peoples', 25 Harvard Human Rights Journal 49, at 51 (2012) (analysing United Nations' treaty body practice 'concerning the rights of indigenous peoples, which suggest[s] a further dimension to the interdependence and indivisibility of human rights. These developments suggest that human rights are interdependent and indivisible not only in terms of mutual reinforcement and equal importance, but also in terms of the actual content of these rights') (footnote omitted). See also e.g. Xákmok Kásek v. Paraguay, above n. 100, at 263, and Río Negro Massacres v. Guatemala, above n. 54, at 143-44 (both relating territorial rights to the rights of the child).

116. See inter alia Maya Indigenous Communities and their Members v. Belize, IACHR, Case 12.053 (2003), 111-19, 141; CCPR/CO/69/AUS (2000), 10-11; and; G. Handl, 'Indigenous Peoples' Subsistence Lifestyle as an Environmental Valuation Problem', in M. Bowman and A. Boyle (eds.), Environmental Damage in International and Comparative Law. Problems of Definition and Valuation (2002), at 95 (asserting 'there can be little room for doubt that there exists today a general consensus among states that [indigenous peoples'] cultural identity ... warrants affirmative protective measures by states, and that such measures be extended to all those elements of the natural environment whose preservation or protection is essential for the groups' survival as culturally distinct peoples and communities').

117. Kaliña and Lokono peoples, above n. 1, at 295.

118. Id., at 217

119. Id., at 222 
damaged and the landscape altered radically'. ${ }^{120}$ It ruled in this respect that the state had violated the victims' rights to collective property, cultural identity ${ }^{121}$ and participation in public matters. ${ }^{122}$ Note in this regard that, in Sarayaku, the Court observed that respect for the right to consultation of indigenous peoples 'is precisely recognition of their rights to their own culture or cultural identity ... which must be assured, in particular, in a pluralistic, multicultural and democratic society'. 123

Leaving aside the equation of recognition of rights to culture or to cultural identity with the right to consultation, not the least as the latter would not seem, by itself, to ensure the substantive guarantees inherent in said rights, the Court could have found that the proven acts and omissions do, as a matter of fact and law, 'negate the very survival' of the Kaliña and Lokono, and therefore, that the impugned activities were impermissible. It could have plausibly done so in relation to the bauxite mining alone based on its factual findings. Cumulatively, the facts of the case strongly support finding that the activities in question do threaten, and likely also negate, the Kaliña and Lokono's 'ability to "preserve, protect and guarantee the special relationship that they have with their territory", so that "they may continue living their traditional way of life, and that their distinct cultural identity, social structure, economic system, customs, beliefs and traditions are respected, guaranteed and protected"', the ultimate purpose of the protections specified by the Court.

However, despite being extensively briefed by the Kaliña and Lokono, these issues are not analysed or otherwise adequately addressed in the judgment. The Court, for example, could have concluded that the activity or activities did not rise to the requisite level (e.g. finding that serious and enduring damage to natural resources necessary for survival and development and inter-generational harm to the cultural identity of the Kaliña and Lokono does not pass the threshold), but this point was not explicitly addressed. The redress provided for the

120. Id., at 220

121. Sarayaku, above n. 28, at 217 (explaining that 'the right to cultural identity is a fundamental right - and one of a collective nature - of the indigenous communities, which should be respected in a multicultural, pluralistic and democratic society. This means that States have an obligation to ensure that indigenous peoples are properly consulted on matters that affect or could affect their cultural and social life, in accordance with their values, traditions, customs and forms of organization').

122. Kaliña and Lokono peoples, above n. 1, at 198 (finding these violations to have been caused 'mainly by preventing their effective participation, and the access to part of their traditional territory and natural resources, in the Galibi and Wane Kreek nature reserves, as well as by failing to guarantee, effectively, the traditional territory of the communities that has been affected by the environmental degradation within the WKNR'). See also Sarayaku, above n. 28, at 218-20, at 220 (where the Court 'considers that the failure to consult the Sarayaku People affected their cultural identity, since there is no doubt that the intervention in and destruction of their cultural heritage entailed a significant lack of respect for their social and cultural identity, their customs, traditions, worldview and way of life, which naturally caused great concern, sadness and suffering among them').

123. Id., at 159 serious pecuniary and non-pecuniary damages, taken together with the Court's reasoning and other orders, may allow some conclusions to be drawn implicitly, but this provides very little assistance to states or indigenous peoples about the parameters within which rights should be recognised, respected and protected or how projects and investments should be assessed and permitted. This is all the more disturbing given the hotly contested nature of many of these issues.

Patrick Macklem has correctly observed in this regard that the more specific the descriptions international law offers of what changes are needed in domestic law, the more the intervention translates relatively abstract international human and indigenous rights into concrete legal entitlements cognizable to the domestic legal order in question in a programmatic way.... 124

The Court's approach in Kaliña and Lokono not only fails in this test, it also risks relegating the Court's selfdesignated ultimate purpose (ensuring survival as defined above) for the various protective measures to little more than rhetoric. The same may also be said for equating rights protection with consultation or participation but not analysing or requiring consent; the latter, assuming it is implemented properly, being a fundamentally more effective means by which indigenous peoples can protect the substantive guarantees that are usually threatened by extractive, conservation and other projects.

Moreover, this equation of rights protection with consultation generally leads the Court to emphasise procedural guarantees at the expense of fully contemplating and ruling on substantive guarantees and violations thereof. This is especially troubling as consultation processes are often deeply flawed and, if they happen at all, the inequality of arms between states, corporations and indigenous peoples is conspicuous and often debilitating. This focus also does little to prevent future violations as the various judgments tend to revolve around state compliance with procedures, rather than, as Macklem observes above, providing specific analysis of rights in a way that makes them cognisable to the domestic legal order and authorities 'in a programmatic way'. It also results in an undue emphasis on permissible restrictions to rights, rather than focusing on the content of those rights, which brings to mind Yash Gai's comment that 'rights are struggling to stay afloat in the sea of exceptions (and alas not always succeeding!)' ${ }^{125}$

Turning to consent, in Saramaka, the Court held that the effective participation standard includes consent when a large-scale project or projects, separately or cumulatively, 'would have a major impact' on traditional

124. Paper by Professor Patrick Macklem, UN Seminar on Access to Justice, cited in Access to Justice in the Promotion and Protection of the Rights of Indigenous Peoples, A/HRC/24/50 (2013), at 18, footnote 19.

125. Y. Ghai, 'The Kenyan Bill of Rights: Theory and Practice', in P. Alston (ed.), Promoting Human Rights through Bills of Rights: Comparative Perspectives (1999), at 197. 
territory. ${ }^{126}$ Nonetheless, in Kaliña and Lokono, the Court maintains its post-Saramaka trend of minimising or omitting any discussion of the consent requirement, emphasising only the (albeit considerably strengthened) consultation aspects of effective participation. ${ }^{127}$ In its 2013 decision on the merits in Kalina and Lokono, the IACHR observed that the mining operations at issue certainly triggered the consent requirement. ${ }^{128}$ The Court's verification of the scale and impact of these operations should have prompted it to assess, or at least acknowledge, consent, even if it then relied on the lack of consultation as reason for not analysing its applicability. ${ }^{129}$ It not only failed to do so, it even omitted the word 'consent' when quoting Article 32(2) of the UNDRIP in the relevant section of the judgment. ${ }^{130}$

This is troubling to the say the least in light of the repeated affirmation of consent - as an attribute of indigenous peoples' right to self-determination - by UN treaty bodies and others. Ironic also, given that the Committee on Economic, Social and Cultural Rights routinely cites consent as being required under Article 1 of the Covenant ${ }^{131}$ and the Court has twice held that it cannot interpret the rights guaranteed to indigenous peoples by the ACHR to a lesser extent than is recognised in that same Covenant. ${ }^{132}$ Yet, this is precisely what it did in Kaliña and Lokono.

\section{Conclusion}

The contemporary indigenous rights framework has come into being via three main processes, all within the

126. Saramaka People, above n. 22, at 134, 137 and 147

127. Sarayaku, above n. 28 , at 177 (stating that it was unnecessary to assess the consent requirement because the State had failed to consult); accord Garifuna Community of Triunfo de la Cruz v. Honduras, IACTHR (2015) Series C, No. 305, Garifuna Punta Piedra Community v. Honduras, above n. 81.

128. Kaliña and Lokono Peoples v Suriname, IACHR, Case 12.639, above n. 3 , at 155 (concluding that the bauxite mining in this case 'is precisely the type of activity that the Inter-American Court has stated should be subject to consultations and consent of the affected indigenous peoples. In Saramaka, the Court stated that "regarding large-scale development or investment projects that would have a major impact within Saramaka territory, the State has a duty, not only to consult with the Saramaka, but also to obtain their No consultation or consent of this type was conducted or obtained in connection with the authorization of bauxite mining operations inside the Wane Kreek Reserve').

129. Sarayaku, above n. 28, 180 and footnote 237.

130. Kaliña and Lokono Peoples, above n. 1, at 202.

131. See e.g. E/C.12/PRY/CO/4, above n. 42, at 6 (citing Art. 1, and recommending that Paraguay adopts 'the legislative and administrative measures needed to ensure that free, prior and informed consent is obtained from indigenous peoples in relation to decisions that may directly affect the exercise of their economic, social and cultural rights'); and E/C. 12/AUS/CO/5 (2017), at 16(e) (citing Art. 1, and recommending that Australia ensure that 'free, prior and informed consent is incorporated in the Native Title Act 1993 and in other legislation as appropriate, and is fully implemented in practice');

132. Saramaka People, above n. 22, 93; Kaliña and Lokono Peoples, above n. 1, 122 and, at 124 (stating that 'in this case, the right to property protected by Article 21 of the [ACHR], and interpreted in light of the rights recognized in Article 1 common to the two Covenants, ... which cannot be restricted when interpreting the American Convention...'). context of highly effective advocacy by indigenous peoples at the international (and, in some cases, domestic) level. First, the interpretation of existing international human rights norms in a way that is more responsive to indigenous characteristics and needs. Second, the promulgation of specific international instruments, wholly or partially, addressing indigenous rights, and within different fields of international law; and third, litigation before international courts and quasi-judicial bodies. ${ }^{133}$ The above discussion of Kaliña and Lokono Peoples and the UNDRIP indicates that these are not discrete categories, but, instead, operate in a dynamic state of interplay and, often, mutual reinforcement. This also affirms that the UNDRIP is only one, albeit very important, bright light in the firmament that 'stretches well beyond international legal regimes and into State and indigenous forums alike'. ${ }^{134}$

The Court is a leading actor in this process, as is the IACHR, which first addresses and then brings cases to the Court. Its judgments have incorporated, inter alia, important elements of self-determination, including as (inter)related with issues of legal personality and rights to collective territory; some attributes of the right to self-government via recognition of the right to control territory and respect for indigenous institutions and juridical and other procedures; effective participation in external decision-making, including, in principle at least, consent (itself an attribute of self-determination); and ground-breaking collective reparations, including detailed norms on restitution of lands, that strive to be highly attuned to indigenous realities and concerns. While it has a tendency to essentialise indigenous culture and rights, often over emphasising its perception of 'traditional', its detailed reasoning and associated orders are remarkable. ${ }^{135}$ The same may also be said for the Court's consistent recognition of indigenous customary law and its insistence that States respect indigenous peoples' 'customs, traditions and land tenure systems'. ${ }^{136}$ This recognition of indigenous customary law 'has afforded greater protection of indigenous property rights, which are essential to self-determination, selfgovernance, and continued cultural existence'. ${ }^{137}$

While only touched on above, Kaliña and Lokono also illustrates how indigenous rights litigation may - and often should - encompass different fields of international law, always with the aim of harmonising them with human rights guarantees. The Court, for instance,

133. See e.g. R. Morgan, Transforming Law and Institution: Indigenous Peoples, the United Nations and Human Rights (2011).

134. K. Carpenter and A. Riley, 'Indigenous Peoples and the Jurisgenerative Moment in Human Rights', 102 California Law Review 173 (2014), at 175.

135. See e.g. Price, above n. 20, at 237-40, at 238 (observing 'a disturbing essentialist leaning in some of the Court's reasoning;' and pointing out 'the fundamental tension that exists between ideas that undergird relevant aspects of international human rights law and current ideas in anthropology').

136. Kaliña and Lokono Peoples, above n. 1, 139, footnote 178 (citing and paraphrasing UNDRIP, Art. 26).

137. Carpenter and Riley, above n. 134, at 207. See also B. Tobin, Indigenous Peoples, Customary Law and Human Rights - Why Living Law Matters (2014) (addressing these issues in detail). 
extensively cites international environmental law, reading provisions of the Convention on Biological Diversity (CBD) into its interpretation of the ACHR, ${ }^{138}$ and stresses, as a general proposition, that 'the rights of the indigenous peoples and international environmental laws should be understood as complementary, rather than exclusionary, rights'. ${ }^{139}$ It is important to note that, although the CBD purports to guarantee some indigenous rights, there is no corresponding enforcement mechanism. The Court's ruling provides an opportunity to enforce some $\mathrm{CDB}$ provisions through the lens of the ACHR.

One area where much greater attention is required is the intersection between indigenous rights and trade, investment and private sector operations. ${ }^{140}$ Even though many of the cases resolved by the IACHR and the Court have involved private sector entities, especially in the extractives sector, the role and potential liability of the private sector has yet to be addressed. Kaliña and Lokono Peoples has generated some interest with respect to the UN Guiding Principles on Business and Human Rights and this may be further developed in future cases. However, other possible avenues also require attention and strategic action.

In the first place, states have previously invoked bilateral and other investment or trade agreements to reject increased regulation of transnational corporations operating on indigenous lands. Yet, the Court clearly held in Samhoyamaxa that such agreements are subordinate to the ACHR, calling into question the legality of range of prior expropriations of indigenous lands as well as the activities now taking place on those lands. ${ }^{141}$ This is also highly significant as the majority of loan agreements between states and international financial institutions (e.g. the World Bank Group) are classified as bilateral treaties, and some of the projects carried out pursuant to those agreements have had and continue to have severe, negative human rights impacts on indigenous peoples. Also, while not referenced by the Court in Samhoyamaxa, it is important to recall that Article 36 of the Charter of the OAS provides that 'Transnational enterprises and foreign private investment shall be subject to the legislation of the host countries and to the jurisdiction of their competent courts and to the international treaties and agreements to which said countries are parties...' It would seem logical that the Court would accord the same primacy to the ACHR in this context

138. Kaliña and Lokono Peoples, above n. 1, at 177 (quoting and incorporating Arts. $8(\mathrm{j})$ and 10 (c) of the $(B D)$.

139. Id., 173.

140. See e.g. Report of the Special Rapporteur of the Human Rights Council on the rights of indigenous peoples on the impact of international investment and free trade on the human rights of indigenous peoples, A/70/301 (2015)

141. Sawhoyamaxa Indigenous Community v. Paraguay, above n. 98, at 140 (rejecting the argument that some of the lands in question were protected from expropriation by a trade agreement with Germany; making clear that such agreements must always be interpreted consistently with the ACHR's guarantees and could not be invoked as grounds for noncompliance with those guarantees (i.e. the restitution of indigenous lands). also, and this may provide a way of seeking to further regulate the human rights conduct of both private sector entities and host states.

Finally, it is trite to observe that there is a serious implementation gap in human rights law. This is also the case for compliance with the Court's judgments. While further litigation is unlikely to address this perennial problem, the Court's jurisprudence is nonetheless slowly and surely having an impact on domestic tribunals and legislatures. The Constitutional Court of Colombia, for example, routinely cites the Court as authority, including in cases brought by indigenous peoples. Likewise, the Caribbean Court of Justice accorded great weight to the IACHR and Court's jurisprudence in its landmark 2015 judgment in Maya Leaders Alliance v. A.G. Belize. This judgment, which cited the UNDRIP and a range of other international standards, upheld Maya customary land tenure rights as constitutionally protected property. ${ }^{142}$ In doing so, the CCJ stressed that this was demanded by the concept of the rule of lam, which 'encompasses the international obligations of the State to recognize and protect the rights of indigenous people'. ${ }^{143}$ It also emphatically declared that, today, it is 'beyond dispute that international law recognizes and protects the rights of indigenous peoples' ${ }^{144}$ Times have changed!
142. See also New Zealand Mãori Council et al v. A.G. et al, [2013] NZSC 6 (where the New Zealand Supreme Court relied on the UNDRIP in construing the scope of Mãori rights to freshwater and geothermal resources).

143. Maya Leaders Alliance v. A.G. Belize, [2015] CCJ 15 (AJ), at 52. 144. Id., at 53. 